\title{
Meszesedések a maxillofaciális régióban
}

\author{
DR. NÉMETH BERTALAN, DR. PATAKY LEVENTE, DR. JOÓB F. ÁRPÁD, \\ DR. KOPPÁNY FERENC, DR. BARABÁS JÓZSEF
}

\begin{abstract}
Klinikusként naponta számtalan radiológiai felvétellel találkozunk. A szélesebb régiót leképező felvételeken (például panorámaröntgen, vagy CBCT-felvétel) mellékleteként felfedezhetünk különböző meszes elváltozásokat, kalcifikációkat. A fej-nyak régió leggyakrabban előforduló elváltozásai közé tartozik - a nyálkövességen kívül - a tonsillák, nyirokcsomók, illetve a ligamentum stylohyoideum kalcifikációja, valamint az ereket érintő ateroszklerózis. A közlemény célja, hogy saját eseteinken keresztül összefoglalva bemutassuk ezeket az elváltozásokat, differenciáldiagnosztikai jelentőségüket.
\end{abstract}

Kulcsszavak: meszesedés, tonsillolith, ateroszklerózis, processus styloideus, phlebolith

\section{Bevezetés}

Meszesedésekkel gyakran találkozunk a maxillofacialis régióban, a legismertebb ezek közül a sialolithiasis. Kalcifikáció a savak kalciummal, magnéziummal, vassal vagy egyéb, akár szerves vegyületekkel alkotott oldhatatlan sóinak depozíciója: elsősorban Ca-hidroxi-apatit kristályok vagy más oldhatatlan Ca-sók formájában. Egyik lehetséges megjelenése a disztrófiás meszesedés, ami általában elhalt, beteg, degenerált szövetekben jön létre normális szérum calcium- és foszfátszint mellett. A kalcifikáció nem mindig okoz tüneteket, gyakran véletlenül kerül felfedezésre radiológiai vizsgálat során. A meszesedések igen változatosak lehetnek, méretük az alig észrevehetőtől egészen akár néhány centiméteres átmérőt meghaladóig is tarthat. Gyakori előfordulási helyük: mirigyek, nyirokcsomók, szalagok, ízületi porcok, erekhez köthető elváltozások (pl. ateroszklerotikus plakkok), nekrotizált szövetek, krónikusan gyulladt ciszták és polipok. Legismertebbek a nyálkövek, de terjedelmi okok miatt ezekkel részletesen itt nem foglalkozunk $[28,40]$.

Panorámafelvételen ezek az elváltozások látszódhatnak, azonban a térbeli helyzetük meghatározása és diagnosztikájuk nehézkes lehet. A CBCT megjelenésének köszönhetően egyre több elváltozást fedezhetünk fel véletlenszerüen, amiket pontosan tudunk lokalizálni. Khan és mtsai 308 CBCT-felvételt elemeztek, az esetek 35\%-ban találtak valamilyen kalcifikációt. Leggyakrabban a carotis artériák, a cartilago triticea-k és a tonsillák meszesedését észlelték. A fogászati és maxillofaciális radiológia (DMFR) fejlődése és a diagnosztikai lehetőségek kiszélesedése miatt a témát a gyakorló fogorvosoknak és szájsebészeknek az eddigieknél jobban meg kell ismerni, ezért tűztük ki célul

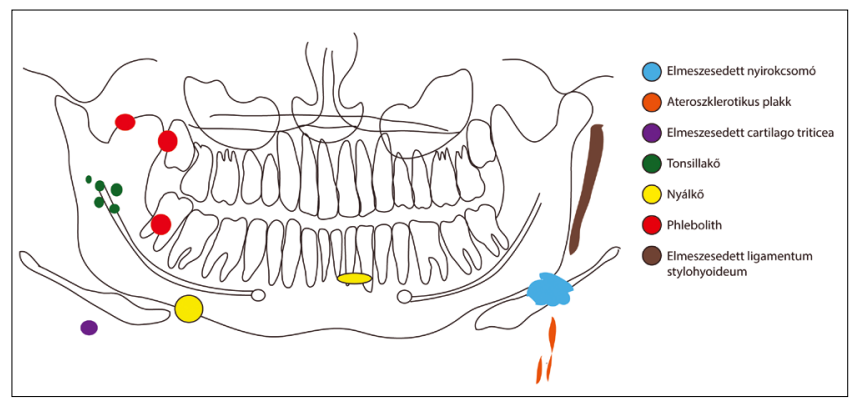

1. ábra: Különböző meszesedések lehetséges lokalizációja (White-Pharoah alapján) [40]

dolgozatunkban a téma átfogó és részletes ismertetését [25]. (1. ábra)

\section{A meszesedések különböző formái}

\section{Tonsillolith}

Pontos etiológiája és patogenezise ismeretlen. Feltehetően visszatérő mandulagyulladás eredményeként alakul ki. A kripták következményes fibrózisa, valamint az elhalt hámsejtek okozta lepedék jó táptalaj a baktériumoknak. Számos eltávolított köveken végzett laboratóriumi tanulmány szerint a dentális biofilm, plakk kialakulásával és meszesedésével azonos folyamatok zajlanak létrejöttének hátterében [36].

Idősebb korban jellemző, nemi különbséget eddig nem figyeltek meg. Előfordulási helye a peritonsillaris régió, az oldalsó garatfal és a nasopharyngealis terület.

A tonsilla palatinában keletkező kövek gyakran nem, vagy csak nehezen diagnosztizálhatók klinikai vizsgálat során, amennyiben látszódnak általában kemény, ke- 
rek, sárga vagy fehér színű, a kriptákból kiemelkedő képletek. Előfordul egy vagy több kő, uni-, illetve bilaterális manifesztáció is. Mikroszkopikusan különböző apatitkristályokból, oxalát- és magnéziumsókból állnak, alakjuk igen változatos: a kerekded formától a szabálytalan piramison át egészen a lebenyezettig bármilyen alak előfordulhat. Eltávolítás után színük lehet fehér, szürkéssárga, vörösbarna vagy fekete. Konzisztenciájuk változó, előfordul puha, morzsolható, de kőkemény is. Az irodalomban eddig leírt legnagyobb kő mérete $25 \times 33 \mathrm{~mm}$, tömege $42 \mathrm{~g}$ volt [5, 8, 21, 30, 32, 34, 36].

A tonsillitis klasszikus tünetei mellett gyakran okoz halitosist, valamint rossz száiízt, ritkábban dysphagiát, arc- és fülfájdalmakat, légúti obstrukciót. A kisfokú meszesedések általában tünetszegények. Panorámafelvételen a tonsillakövek megtévesztően a ramus közepére vetülhetnek, gyakran a canalis mandibulae-ra vagy az alá, ezzel komoly diagnosztikai nehézséget okoznak [3, 10, 26, 29, 34, 37]. (2. ábra)

Tsuneishi és mtsai mikrobiológiai vizsgálataik során a Prevotella törzs tagjait minden esetben kimutatták, a Fusobacterium nucleatum jelenléte is gyakorinak bizonyult a tonsillakövekben. Flórájuk vegyes, egyaránt tartalmaz aerob és anaerob specieseket, a kövek felszínén a különböző coccusok, a belsejükben a pálcikák dominálnak. A következő - kövekben kimutatott - baktériumgenusok a felelősek különböző illékony kénvegyületek szintéziséért, így a következményes halitosisért: Eubacterium, Fusobacterium, Megasphaera, Porphyromonas, Prevotella, Selenomonas és Tannerella [39].

Összehasonlításképpen az alábbi, legismertebb, a szájüregben megtalálható mikroorganizmusokat hozzák összefüggésbe a kellemetlen lehelettel: Bacteroides loeschei, Eikenella corrodens, Enterobacteriaceae, Fusobacterium nucleatum, Porphyromonas endodontalis, Porphyromonas gingivalis, Prevotella intermedia, Tannerella forsythensis, Treponema denticola [35].

A tonsillakövekről az irodalmi adatok különbözőek, Ram és mtsai mindössze két esetben találtak az irodalomban bilaterális elváltozást (1920-2003 között). A cikk szerzői által leírt hatalmas $(3 \times 4$ centiméteres) kő is egyoldali volt, egészen a középvonalig bedombo-

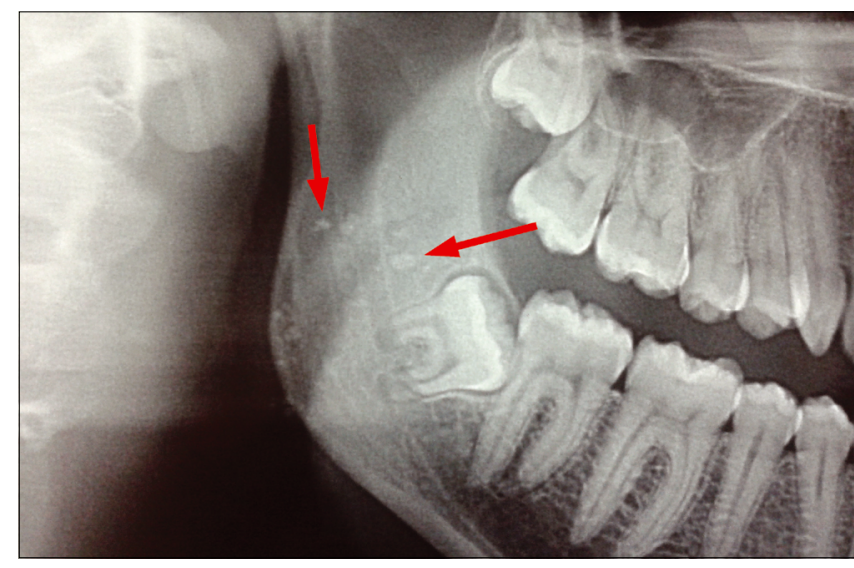

2. ábra: Tonsilla palatina meszesedése panoráma felvételen rodott. Panorámafelvételen kétoldalinak tűnt, az úgynevezett „ghost image” kialakulása miatt [32].

Azóta több közlemény foglalkozik kétoldali kövekkel, a témában egyre több közlemény jelenik meg, feltehetően a digitális képalkotás fejlődésének köszönhetően.

Fauorux és mtsai 150 CT-felvétel elemzése kapcsán megállapították, hogy a populáció közel egynegyedét érinti a tonsilla palatinák meszesedése, de ennek csak töredéke az, ami panorámafelvételen látható [12].

Oda és mtsai 482 panorámafelvételt és ugyanezen páciensek CT-felvételét elemezték.

Mindezeket egymástól függetlenül vizsgálták, anélkül, hogy tudták volna, hogy mely esetben kell számítani az elváltozásra. A panorámafelvételek alapján 37 esetben (7,7\%) valószínüsítették az elváltozást, míg a CT elemzés során 222 páciensnél $(46,1 \%)$ találtak tonsillaköveket, ebből 81 volt bilaterális. Mindössze két páciens esetében volt téves a panorámafelvétel általi diagnózis, a háromdimenziós felvételen meszesedést nem láttak. 179 páciensnél $5 \mathrm{~mm}$-nél nagyobb kövek sem ábrázolódtak egyértelmúen [31].

Centurion és mtsai [7] is hasonló eredményre jutottak. 100 pácienst vizsgáltak, panorámafelvételen 25, míg CBCT-felvételen 61 tonsillolithet fedeztek fel. A vizsgálatok alapján elmondható, hogy több kisebb kő diagnosztizálása könnyebb feladat, mint egy nagyobb, szoliter kőé [31]. (2., 3. ábra)

\section{Meszesedett nyirokcsomók}

A hosszú ideig gyulladásban lévő, hegesedő nyirokcsomókban gyakran granulomatózus betegségek során jön létre a meszesedés. A lymphoid szövet helyett hidroxiapatitszerü kalciumsók elhomályosítják a nyirokcsomó struktúráját. A kalcifikáció jelenléte aktív vagy korábban lezajlott betegségre is utalhat, mint például: tuberkulózis, szarkoidózis, macskakarmolás betegség, reumatoid artritisz, gombás fertőzés, sugárterápiával kezelt lymphoma, illetve tumormetasztázis. Leggyakrabban érintettek a submandibularis, a felületes- és mély nyaki, ritkábban a preauricularis, submentalis nyirokcsomók. Tapintásra ezek a nyirokcsomók kemények, göbösek. Általában panoráma-röntgenképen fedezzük fel őket,

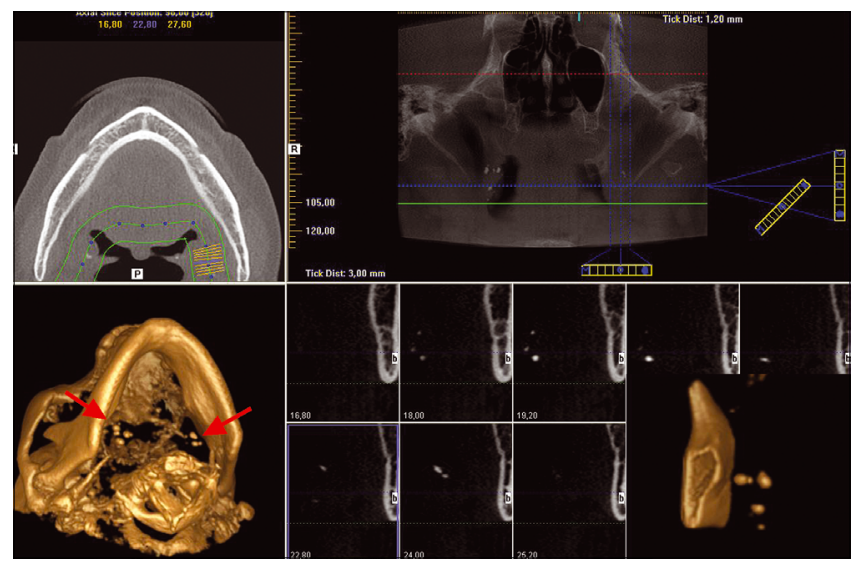

3. ábra: Tonsilla kövek CBCT felvételen 
a mandibula bázisa alatt, közel az angulushoz, vagy a ramus és a gerincoszlop közötti területen. Időnként meszesedett nyirokcsomó láncolatot is megfigyelhetünk. A kontúrja jól kivehető, szabálytalan, néha karfiolra emlékeztető rajzolatot mutat, ez a megjelenés megkülönbözteti más, a régióban előforduló kalcifikációtól (tonsillolith, phlebolith stb.). Előfordulhat, hogy csak a nyirokcsomó felszíne mutat fokozott radioopacitást. A nodus képe nem megbízható rossz-, illetve jóindulatú elváltozások megkülönböztetésére. Ezek a nyirokcsomók általában tünetmentesek, nem igényelnek kezelést, a kiváltó okot (például korábban lezajlott betegség) azonban mindenképpen tisztázni kell [25]. (4. ábra)

\section{Processus styloideus elongatus}

Normális esetben a processus styloideus $20-30 \mathrm{~mm}$ hosszúságú, $40 \mathrm{~mm}$ esetén már elongációról beszélhetünk. A ligamentum stylohyoideum a processus styloideusról ered és a nyelvcsont kis szarván tapad. A populáció 1,4-30\%-ánál látható radiológia vizsgálat során a szalagok kalcifikációja. Általában bilaterálisan, azonban csak ritkán szimmetrikus [20]. (5., 6. ábra)

A processus styloideus anatómiai elváltozásainak csoportosítása:

1) Processus styloideus anomáliái: rendkívüli hossz és megvastagodás; lokalizációbeli eltérés, mediális irányba való elhajlás

2) A ligamentum stylohyoideum elcsontosodása: körülírt csontosodási mag; kiterjedt elcsontosodás, ízületképződéssel vagy anélkül; teljes elcsontosodás

\section{Eagle-szindróma}

A ligamentum stylohyoideum elmeszesedése altalában tünetmentes, de változatos panaszokat is okozhat: nyelési nehezítettség, állkapocsszöglet mögé vagy fülbe sugárzó szúró jellegú fájdalom, torokfájás, diszkomfort érzés, ritkán nyomhatja is az arteria carotis internát, ezt a tünetegyüttest nevezzük Eagle-szindrómának [20].

Az ezzel összefüggő panaszok csoportosítása:

1) Dysphagia, nyelési fájdalom, eredetük a nervus glossopharyngeus irritációja

2) Idegentest-érzés a szájfenéken

3) Különböző irányokba kisugárzó fájdalom: articulatio temporomandibularis, corpus et ramus mandibulae, radix linguae, glandula submandibularis, pharynx, oesophagus, palatum, regio pectoralis $[20,41]$.

Differenciáldiagnosztika szempontból lényeges a fájdaIom lokalizációja, jellege, erőssége, kontinuitása, rohamokban való jelentkezése, kiindulási helye, kisugárzása, illetve a kiváltó ok is. Klinikai vizsgálat során a mandibula ramusától medialisan tapinthatjuk a processus styloideust. Az elülső garatív mentén ujjunkkal felülről lefelé követjük, a nyelvgyök mellett egészen a szájfenékig.

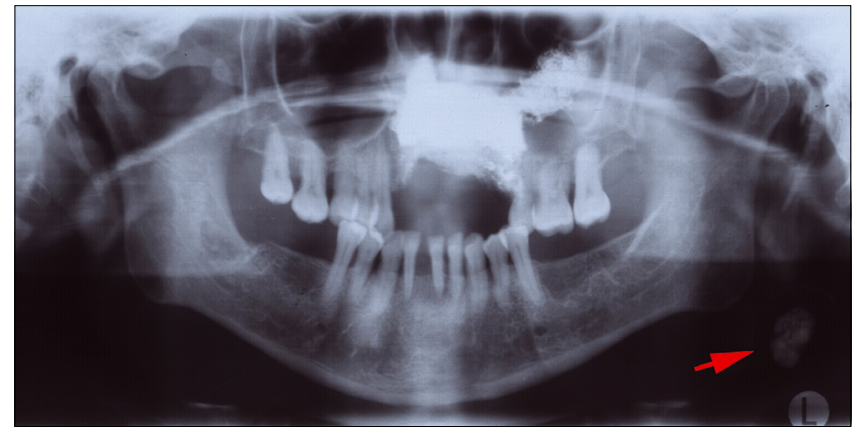

4. ábra: Meszesedett nyirokcsomó panoráma felvételen

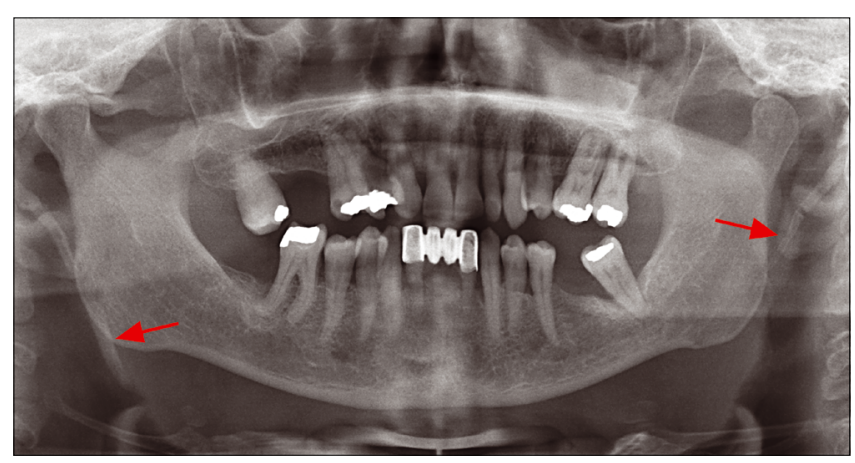

5. ábra: Két oldali processus styloideus elongatus panoráma felvételen

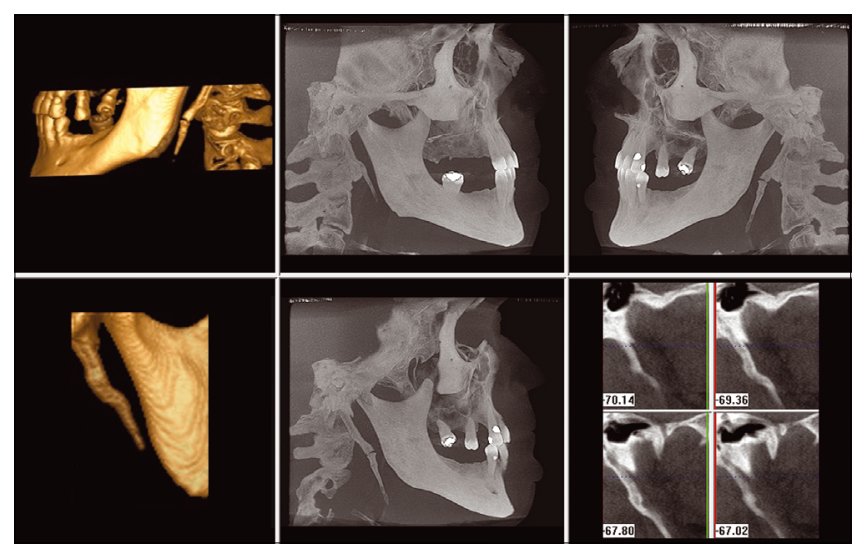

6. ábra: Mindkét oldalon elmeszesedett ligamentum stylohyoideum, bal oldali álízület képződéssel - CBCT felvétel

Panorámafelvételen a meszesedett ligamentum stylohyoideum vetülete a processus mastoideus környékéről indul, a ramus mandibulae hátsó szélét keresztezi és tart lefelé a nyelvcsont irányába. A ligamentum elmeszesedése a röntgenfelvételeken nem mindig homogén, esetenként fúzérszerǔ szerkezetet mutat (calcified stylohyoid chain) $[14,18,27]$.

Röntgenfelvételen történő diagnosztizálása az egymásra vetülő struktúrák miatt nem mindig egyértelmú. Centurion és mtsai 100 pár panorámaröntgent és CBCT-t vizsgáltak, az általuk átnézett esetek $42 \%$-ában a röntgenfelvételen felismerhető volt a meszesedés, míg a CBCT-n a betegek 63\%-nál volt látható [7]. 
Nemcsak az elongáció, hanem a processus styloideus iránya, a normálistól a középvonal felé való eltérés is okozhat panaszt. Kezelés a processus styloideus sebészi eltávolítása $[18,27]$.

\section{DISH (Diffuse Interosseus Skeletal Hypertrophy) szindróma}

A DISH szindróma több különböző néven is ismert (például: Forestier betegség, spondylosis hyperostotica), talán a legmegfelelőbb magyar megfelelője a diffúz idiopátiás szkeletális hiperosztózis megnevezés. Az intervertebrális szalagok elmeszesednek, ennek következtében a páciensek nyaki fájdalmakról panaszkodnak fejforgatás és extenzió alatt, továbbá a ligamentum stylohyoideum is elmeszesedik, ami miatt nyelési fájdalom, Eagle-szindróma alakulhat ki.

Ezenfelül karba kisugárzó fájdalom és/vagy pares-

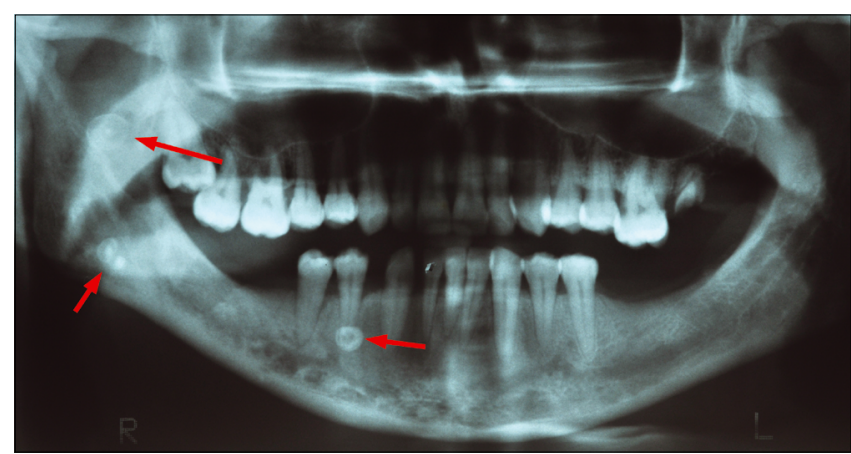

7. ábra: Mandibulára vetülő multiplex phlebolithok - Panoráma felvétel

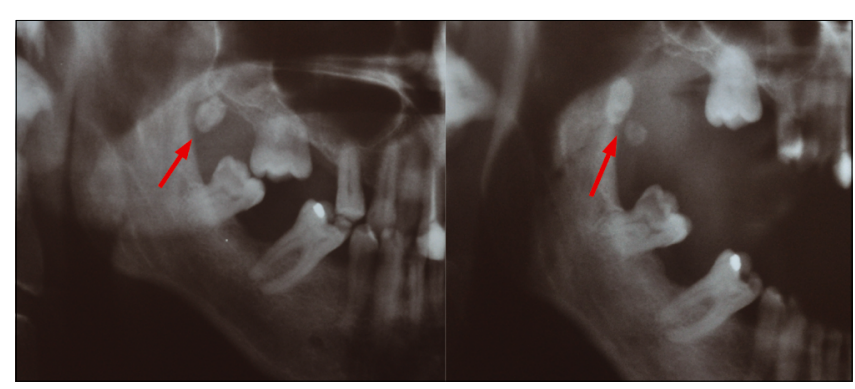

8. ábra: Panoráma felvételen megtévesztő lehet a phlebolithok vetülete - zárt és nyitott állapotú felvételek részletei

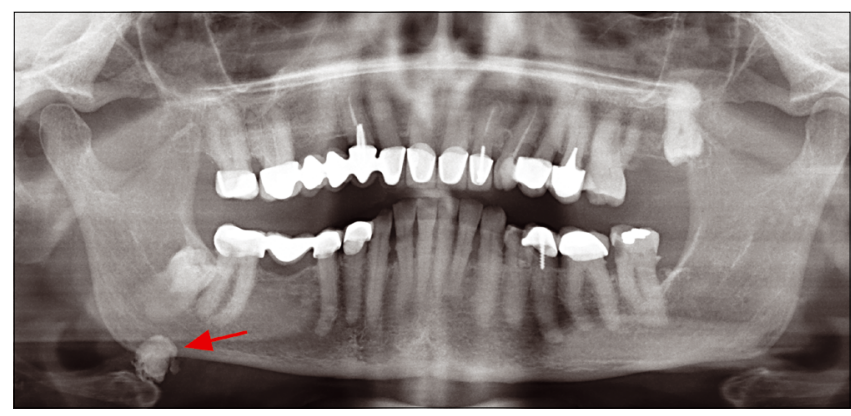

9. ábra: Jobboldali submandibularis nyálkő panoráma felvételen thesia is felléphet a nyaki idegek kompressziója miatt. A betegség általában 40 és 60 éves kor között fordul elő, mindkét nemet egyaránt érinti. Ezek az elváltozások akár egy rutin panorámafelvételen is felismerhetők lehetnek [38].

\section{Phlebolith}

Phlebolithok általában vénákhoz, haemangiomákhoz kötött képletek, csak akkor tapinthatók, ha felületesen helyezkednek el, ami igen ritka. Haemangiomák leggyakrabban - 60\%-ban - a fej-nyak régióban fordulnak elő. A leggyakoribb gyermekkori tumorokhoz tartoznak.

A phlebolithok kialakulásukban valamilyen érrendellenség okozta thrombus képződés játszik szerepet, ami a későbbiekben kalcifikálódik. Kalcium-foszfát és kalcium-karbonát található bennük. A kis phlebolithok röntgenképe általában kerek, homogén, a nagyobb köveké koncentrikus, lamellált, „,hagymaszerú” szerkezetet mutat, gyakran több meszesedett vérrög van jelen egyszerre. Közepük néha radiolucens. A phlebolith radiológiai vetülete nem diagnosztikus értékú, de arra utalhat, hogy egy esetleges haemangioma található az adott régióban, még ha a klinikai vizsgálat során erre utaló jelet nem találtunk is. Fontos megjegyeznünk, hogy ez a fajta lamellált szerkezet nagyobb nyálköveknél is előfordulhat, azonban parotisban ritkán találkozunk olyan méretű sialolithtel, amire ez jellemző lenne. A nyálköveket a ductus általában kissé elnyújtottá „alakítja”. Sialographiával kizárható, hogy a kő a nyálmirigy állományában van-e. Ritkán található egy vagy kettőnél több nyálkő egy adott mirigyben, míg phlebolithból annál gyakrabban fordul elő több, egy adott venosus malformatió-ban. (7., 8., 9. ábra)

Buccában elvétve látunk kalcifikációt, amennyiben mégis előfordul, az leggyakrabban phlebolith. Vérrögből alakul ki, a thrombus meszesedni kezd, megformálva a phlebolith magját. Ehhez kapcsolódik a másodlagosan meszesedő fibrózus komponens. A folyamat ismétlődik, aminek következtében a phlebolith mérete nő $[4,19,23,24,42]$. (7., 8. ábra)

\section{Ateroszklerotikus plakkok a carotisban}

Az erek falában lipidekből és fibrotikus szövetből álló plakkok keletkezhetnek krónikus gyulladás hatására. $\mathrm{Az}$ ateroszklerózis egy multifaktoriális betegség, aminek következménye az erek megvastagodása, elaszticitásuk csökkenése. Az agyat ellátó erek meszesedésének súlyos következményei lehetnek. Számos tényező játszik közre a plakkok kialakulásában: cukorbetegség, elhízás, magas vérnyomás, dohányzás, alkoholizmus, nem megfelelő táplálkozás, fogágybetegség (krónikus vesebetegség, menopauza) stb. Az ateroszklerózis gyermekkorban kezdődik, azonban csak felnőtt korban, általában 45 év felett manifesztálódik.

Elsőként a carotis communis oszlásánál jelenik meg. 
A meszesedés panorámafelvételen általában az angulus mandibulae alatt körülbelül $2 \mathrm{~cm}$-rel figyelhető meg a nyelvcsont és a gerincoszlop által határolt területen. A 3. és 4. nyakcsigolya között fedezhető fel leggyakrabban. Apró, hosszúkás, félkör vagy kagyló alakú radioopak foltokként ábrázolódik. Általában többszörös, szabálytalan alakú elváltozás, ami inkább a vertikális dimenzióban terjed ki. Több mint 30 éve írták le, hogy a panorámaröntgen ilyen jellegú elváltozások kimutatására alkalmas, azóta fokozott figyelem kíséri $[15,43]$. (10. ábra)

Garoff és $m t s a i$ olyan pácienseket vizsgáltak, akiknél korábban carotis stenosist diagnosztizáltak. Megállapították, hogy az esetek 99\%-ában elmeszesedett plakkok találhatók az erek falában, és a páciensek $84 \%$ ánál panorámafelvételen láthatók [13].

Oliveira és mtsai olyan esetet közöltek, amelyben a páciensnél tonsillakövek és carotis meszesedés egyszerre volt jelen [9].

Hoke és mtsai tünetmentes carotis ateroszklerózissal bíró pácienseket vizsgáltak abból a szempontból, hogy van-e összefüggés a panorámafelvételen látható meszesedések és a későbbiekben kialakuló esetleges kardiovaszkuláris események között. A legtöbb publikációval ellentétben megállapították, hogy önmagában a panorámafelvételen diagnosztizálható meszesedésnek nincsenek klinikai következményei, nem befolyásolja az esetleges súlyos, nem várt kardiális esemény bekövetkezésének valószínüségét [17].

Ezt azonban több szerző vitatja. Jelen ismereteink szerint a vita teljes bizonyossággal nincs lezárva $[9,13]$.

\section{Gégeporcok meszesedései}

A cartilago triticea a ligamentum thyrohyoideum lateraleban található apró kis porc, általában a harmadik nyakcsigolya magasságában.

Fokozott kalcifikációja gyakran előfordul, panorámafelvételen közvetlen a nyelvcsont nagy szarva alatt ábrázolódhat apró kerek radioopak foltként. Férfiaknál 29\%, nőknél 22\%-ban fordul elő a meszesedése. Jóindulatú elváltozás, panaszt nem okoz. Fontos elkülöníteni az esetlegesen előforduló carotis meszesedéstől, ami általában panorámafelvételen laterálisabban fedezhető fel és alakja kevésbé szabályos. Kamikawa és mtsai cadaveren végzett kísérletekkel bemutatták az egyes anatómiastruktúrák panorámafelvételen történő differenciál diagnosz-

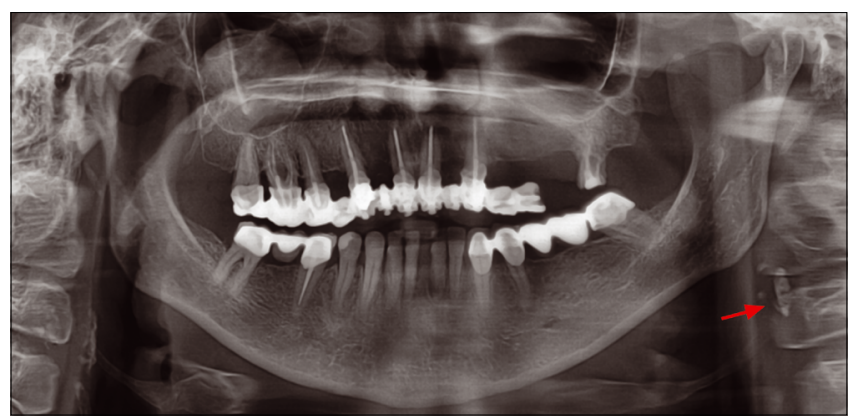

10. ábra: Későbbiekben ultrahanggal igazolt carotis atheroszklerózis panoráma felvételen tikai nehézségét, továbbá megállapították, hogy a klinikusok leggyakrabban a cartilago triticea meszesedését diagnosztizálják tévesen ateroszklerózisnak [2, 6, 16, 22].

A cornu superius cartilaginis thyroidea meszesedésének szintén lehet jele röntgenfelvételeken. Panorámafelvételen általában egy körülbelül $4 \mathrm{~mm}$ széles és $15 \mathrm{~mm}$ hosszú radioopak elváltozás látható a 4 . nyakcsigolya vetületétól medialisan. Általában a cartilago triticea és a carotis bifurcatióhoz képest valamivel lejjebb vetül [33].

\section{Egyéb, ritkán előforduló meszesedések}

Az arc- és orrüregben is létrejöhet meszesedés, kövesedés amelyeket antro-, illetve rhinolithnek nevezünk. Cysticercosisban apró, kerek, meszesedett parazitákat láthatunk. Izomban a rostok nyomása miatt ovális alakot vehetnek fel. Különböző ciszták is elmeszesedhetnek, ezek általában felületesek. A myositis ossificansnak több formája ismert, általában lineáris csíkos morfológiát mutat. Az elmeszesedett acnek hópehelyszerü radiológiai képet mutatnak, klinikailag könnyen elkülöníthetők. Exostosik, osteomák vetülete is megtévesztő lehet $[4,11,40]$.

\section{Összefoglalás}

Panoráma- és CBCT-felvételeken gyakran látunk különböző meszesedéseket főleg a nyakon, a nyelvcsont és a garat környékén. A leggyakrabban ezek panaszt nem okoznak, véletlenszerüen kerülnek felfedezésre. Röntgenfelvételen az adott struktúrák egymásra vetülése miatt diagnosztikai nehézségekkel kell számolnunk. CBCT-felvételen nagyobb biztonsággal diagnosztizálhatunk ilyen elváltozásokat. Az így felfedezhető elváltozások közül el kell tudnunk különíteni a teljesen ártalmatlanokat azoktól, amelyek a továbbiakban figyelmet és más szakorvosok bevonásával további vizsgálatokat és kezelést igényelnek.

\section{Irodalom}

1. Friedlander AH, Lande A: Panoramic radiographic identification of carotid arterial plaques. Oral Surg Oral Med Oral Pathol 52 (1981), pp. 102-104.

2. Ahmad M, Madden R, Perez L: Triticeous cartilage: prevalence on panoramic radiographs and diagnostic criteria. Oral Surg Oral Med Oral Pathol Oral Radiol Endod 2005; 99: 225-230.

3. BABU TA, JOSEPH N: Persistent earache due to tonsillolith. $M$ Indian Pediatr 2012 Feb; 49(2): 144-145.

4. O'RIORdan B: Phleboliths and salivary calculi. Br J Oral Surg, 12 (1974), pp. 119-131.

5. Caldas MP, Neves EG, Manzi FR, de Almeida SM, Bóscolo fN, Haiter-Neto F: Tonsillolith - report of an unusual case. Br Dent $J$ 2007 Mar 10; 202(5): 265-273.

6. CARTER LC: Discrimination between calcified triticeous cartilage and calcified carotid atheroma on panoramic radiography. Oral Surg Oral M Pathol Oral Rad Endod 2000: 108-110. 
7. Centurion B, Imada T, Pagin O, Capelozza A, Lauris J, Rubira-BulLEN I: How to assess tonsilloliths and styloid chain ossifications on cone beam computed tomography images. Oral Dis $2013 \mathrm{Jul}$; 19(5): 473-478.

8. de Moura MD, Madureira DF, Noman-Ferreira LC, Abdo EN, de Aguiar EG, FreIRE AR: Tonsillolith: a report of three clinical cases. Med Oral Patol Oral Cir Bucal 2007 Mar 1; 12(2): 130-133.

9. de Oliveira Cde N, Amaral tM, Abdo EN, Mesquita RA: Bilateral tonsilloliths and calcified carotid atheromas: case report and literature review. J Craniomaxillofac Surg 2013 Mar; 41(2): 179-182.

10. Enciso R, Shigeta Y, Nguyen M, Clark GT: Comparison of conebeam computed tomography incidental findings between patients with moderate/severe obstructive sleep apnea and mild obstructive sleep apnea/healthy patients. Oral Surg Oral Med Oral Pathol Oral Radiol. 2012 Sep; 114(3): 373-381.

11. EnNIs IM, BerRy HM, PhILIPS, JE: Dental Roentgenology, 6th Ed. London, Kimpton, 1967; 593-625.

12. Fauroux MA, Mas C, Tramini $P$, Torres JH: Prevalence of palatine tonsilloliths: a retrospective study on 150 consecutive CT examinations. Dentomaxillofac Radiol. 2013; 42(7): 2012.04.29.

13. Garoff M, Johansson E, Ahlqvist J, Jäghagen El, Arnerlöv C WESTER P: Detection of calcifications in panoramic radiographs in patients with carotid stenoses $\geq 50 \%$. Oral Surg Oral Med Oral Pathol Oral Radiol. 2014 Mar; 117(3): 385-391.

14. Gossman JR, Tarsitano JJ: The styloid-stylohyoid syndrome. J Oral Surg 1977; 35: 555-560.

15. Guimarães Henriques JC, Kreich EM, Helena Baldani M, Luciano M, Cezar de Melo Castilho J, Cesar de Moraes L: Panoramic radiography in the diagnosis of carotid artery atheromas and the associated risk factors. Open Dent J 2011; 5: 79-83.

16. Hately W, Evison G, Samuel E: The pattern of ossification in the laryngeal cartilages: a radiological study. Brit J Radiol 1965; 38: 585.

17. Hoke M, Schmidt B, Schillinger T, Kluger W, Wiesbauer F, MleKUSCH W ÉS MTSAI: Evidence of carotid atherosclerosis in orthopantomograms and the risk for future cardiovascular events. Vasa 2010 Nov; 39(4): 298-304.

18. Ilguy M, Ilguy D, Guler N, Bayirli G: Incidence of the Type and Calcification Patterns in Patients with Elongated Styloid Process. J Int Med Re. 2005; 33: 96-102.

19. Mulliken JB, Fishman SJ, Burrows PE: Vascular anomalies. Curr Probl Surg 37 (2000), 517-584

20. LELKES KL, InOVAY J: Adatok a processus styloideus syndromához. Orvosképzés 50. 1975; 152-155.

21. HiRanandani LH: A giant tonsillolith. J Laryngol Otol 81(1967), 819-822.

22. Kamikawa RS, Pereira MF, Fernandes A, Meurer MI: Study of the localization of radiopacities similar to calcified carotid atheroma by means of panoramic radiography. Oral Surg Oral Med Oral Pathol Oral Radiol Endod. 2006 Mar; 101(3): 374-378.

23. Kanaya H, Saito $Y$, Gama N, Konno W, Hirabayashi H, Haruna S: Intramuscular hemangioma of masseter muscle with prominent formation of phleboliths: a case report. Auris Nasus Larynx 2008 Dec; 35(4): 587-591.
24. Kato H, Ota Y, Sasaki M, Arai T, Sekido Y, Tsukinoki K: A phlebolith in the anterior portion of the masseter muscle. Tokai $J$ Exp Clin Med 2012 Apr 20; 37(1): 25-29.

25. Khan Z, Wells A, Scarfe W, Farman A: Cone Beam CT isolation of calcifications in the maxillofacial and cervical soft tissues: A retrospective analysis. Int J Computer Assist Radiol Surg 2008; 3(Suppl 1): S221-S222.

26. Kıм KS: Referred otalgia induced by a large tonsillolith. Korean $J$ Fam Med 2013 May; 34(3): 221-223.

27. Keur JJ, Campbell JP, McCarthy JF, Ralph WJ: The clinical significance of the elongated styloid process. Oral Surg Oral Med Oral Pathol 1986; 61: 399-404.

28. Kopper L, SChAfF Zs: Patológia I. Medicina, Budapest 2006; 66-67.

29. Lo RH, CHANG KP, CHU ST: Upper airway obstruction caused by bilateral giant tonsilloliths. J Chin Med Assoc $2011 \mathrm{Jul}$; 74(7): 329-331.

30. Misirlioglu M, Nalcaci R, Adisen MZ, Yardimci S: Bilateral and pseudobilateral tonsilloliths: Three dimensional imaging with cone-beam computed tomography. Imaging Sci Dent. 2013 Sep; 43(3): 163-169.

31. Oda M, Kito S, Tanaka T, Nishida I, Awano S, Fujita Y és mtsai: Prevalence and imaging characteristics of detectable tonsilloliths on 482 pairs of consecutive CT and panoramic radiographs. BMC Oral Health 2013 Oct 14; 13: 54.

32. Ram S, Siar CH, Ismail SM, Prepageran N: Pseudo bilateral tonsilloliths: a case report and review of the literature. Oral Surg Oral Med Oral Pathol Oral Radiol Endod 2004 Jul; 98(1): 110-114.

33. Salman RA, Kinney LA: Calcified thyroid cartilage. Oral Surg Oral Med Oral Pathol 1990; 70: 806-807.

34. Siber S, Hat J, Brakus I, Biočıć J, Brajdić D, Zajc I És mtsal: Tonsillolithiasis and orofacial pain. Gerodont 2012 Jun; 29(2): e1157-1160.

35. Scully C, Greenman J: Halitology (breath odour: aetiopathogenesis and management). Oral Dis 2012 May; 18(4): 333-345.

36. Stoodley P, Debeer D, Longwell M, Nistico L, Hall-Stoodley L, WENIG B ÉS MTSAI: Tonsillolith: not just a stone but a living biofilm. Otolaryngol Head Neck Surg 2009 Sep; 141(3): 316-321.

37. Tanigawa T, Yamashita Ji, Shibata R, Shinohara A: A tonsillolith: Possible Cause of Halitosis. Am J Med Sci 2012 jun. 26.

38. Unlu Z, Orguc S, Eskilzmir G, Aslan A, Bayindir P: Elongated styloid process and cervical spondylosis. Clin Med Case Rep. 2008 May 27; 1: 57-64.

39. Tsuneishi M, Yamamoto T, Kokeguchi S, Tamaki N, Fukuı K, WatanABE T: Composition of the bacterial flora in tonsilloliths. Microbes Infect 2006 Aug; 8(9-10): 2384-2389.

40. White SC, Pharoah MJ: Oral Radiology: principles and interpretation. 7th ed. St. Louis: Mosby; 2014: 524-540.

41. WinkLMAIR M: Stoma 24 1971: 205.

42. Zengin AZ, Celenk P, Sumer AP: Intramuscular hemangioma presenting with multiple phleboliths: a case report. Oral Surg Oral Med Oral Pathol Oral Radiol 2013 Jan; 115(1).

43. Zhdanov VS, SteRnBy NH: Monitoring of atherosclerosis. Int J Cardiol 2004; 95: 39-42.

\section{Németh B, Pataky L, Joób Á, Koppány F, Barabás J}

\section{Calcifications in the maxillofacial area}

Among patients presenting for dental treatment we could reveal various calcifications on panoramic x-rays or on cone beam computed tomography (CBCT) Calcifications is more likely to occur in vessels, ligaments, glandular tissues and is usually associated with chronic inflammation or scarring. The purpose of this article is to describe the imaging characteristics of commonly observed calcifications of the maxillofacial area with presenting our own cases such as: tonsilloliths, calcified lymph nodes, elongeated styloid process (calcified stylohyoid chain), phleboliths, carotid atheromas, calcified laryngeal cartilage.

Keywords: calicification, tonsillolith, atherosclerosis, styloid process, phlebolith 